\title{
An Exploration Of Individual And Contextual Factors Affecting The Use Of Contraceptives In Urban Slums Of Pakistan: A Socio-Ecological Analysis
}

\author{
Fauzia Maqsood \\ Department of Sociology \\ University of Gujrat, Pakistan \\ Steven M. Albert \\ Department of Behavioral and Community Health Sciences \\ Graduate School of Public Health, University of Pittsburgh, USA
}

\begin{abstract}
We examined determinants of ever use of contraceptives among women living in urban slums of Pakistan. Data were drawn from a nationwide study, "Living Conditions in Urban Slums of Selected Cities of Pakistan," jointly conducted by University of Gujrat; UNFPA, Islamabad; and UN Habitat, Islamabad, Pakistan. The sample consisted of 2420 married women from six cites. The study was conducted within the socio-ecological framework and examined individual, social, and geographic contextual factors. Multivariate logistic regression model with robust standard errors was used to estimate the contribution of different socio-ecologic factors for use of contraception. Results of logistic regression showed that individual, social, and geographic factors affect use of contraceptives among women in Pakistani urban slums. The socio-ecologic model can help to identify correlates of contraceptive use, especially among developing nations.

تلخيصِ مقال

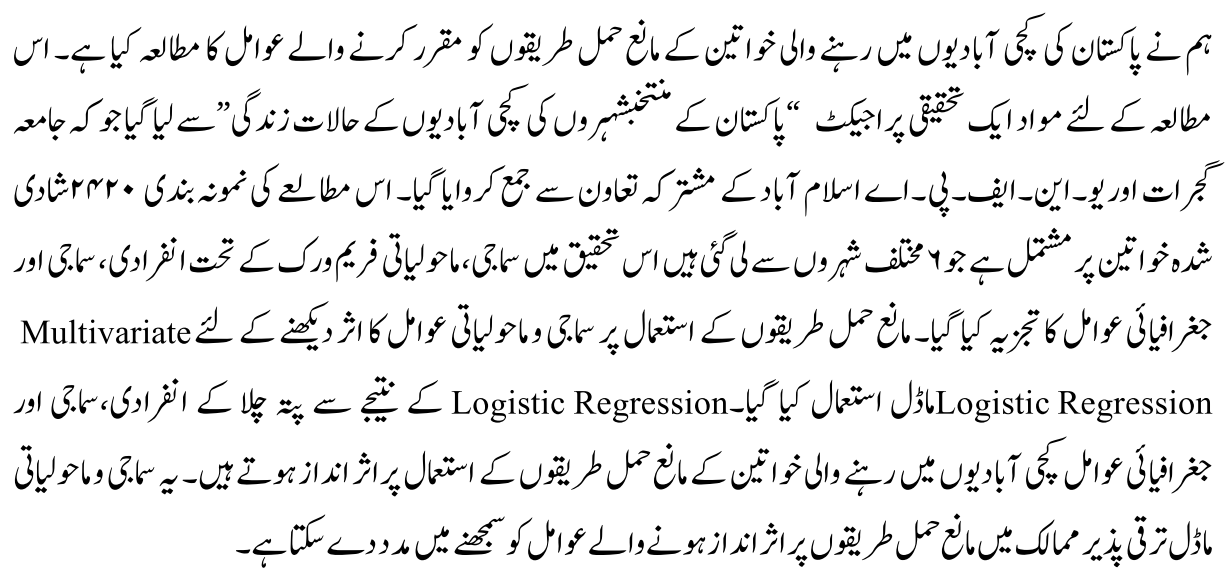

Key Words: Contraception, Social Environment, Socioeconomic Status 

Slums of Pakistan: A Socio-ecological Analysis

\section{Introduction and Background}

Although Pakistan has supported family planning for more than five decades, fertility rates remain high compared to other South Asian countries. Pakistan is projected by the United Nations to be fifth in population by 2050 with 292 million people, after India, China, the United States, and Indonesia (UN 2009).

Research has focused on the limited success of Pakistan's family planning program. One explanation involves social and cultural values that do not favor use of contraceptives. Use of family planning services conflicts with religious values (Fikree et al 2001). Other research suggests that the family planning program has not been well implemented and remained inaccessible to millions of Pakistanis (Hardy and Leahy 2008), resulting in increased pregnancies (Westoff and Bankole2000).

Many predictors of contraceptive use have been identified, such as spousal communication on family size (Hamid, Stephenson \& Rubenson 2011; Fikree et al 2001), education level of the wife, socio-economic status, number of living children (Agha 2001; Casterline, Sathar \& Haque 2001; Axinn and Barber 2001; Axinn and Yabiku 2001; Sultan, Cleland \& Ali 2002; Douthwaite and Ward 2005; Saleem and Bobak 2005; Schultz 2008; Agha 2010; Kamal and Islam 2010), exposure to family planning messages on electronic media ${ }^{3}$,social exclusion of women, and region and residences (Ali and White2005).Other factors include preferences for bearing sons, fear of side effects of contraceptive use, women's autonomy, and husband and in-law opposition (Stephenson \& Hennink 2004; Durrant and Sathar 2000; Winkvist and Akhtar 2000). Men's attitudes were also studied (Casterline et al 2001; Mason 2000; Bhatti \& Hakim 1996) and indicate male preference to limit family size because of economic reasons.

Pakistan's family planning program has been evaluated by several researchers (Hakim 2001; Hakim and Miller 2001), who found greater use of contraception associated with the Lady Health Worker Program (Douthwaite and Ward 2005), political support (Sultan et al 2002), Green Star franchised clinics(McBride and Ahmed 2001; Toll and Agha 1999) and clinical family planning services in urban Pakistan (McBride and Ahmed 2001).

Research on the relationship between environment and population growth gave mixed results (Dunlap, Gallup \& Gallup 1993). Researchers argue that people prefer to have small family size with declining environment (Haq, Vanwing \& Hens 2010). Ghimire and Mohai (2005) reported that with environmental degradation (for example, crop reduction, reduced level of ground water table, and water quality), contraceptive use increases. However, Biddlecom, Axinn, and Barber (2005) found that environmental degradation was associated with a preference for larger families. 
Given these conflicting results, the proposed study examines use of contraceptives in urban slums of Pakistan using a socio-ecologic framework and a multilevel analysis. We examined individual, social, and community factors. An important question is whether community or area-level factors explain variance in contraception use after adjustment for individual and social factors typically assessed in survey research. These geographic factors suggest a need for policy and environmental change to support family planning.

\section{Socio-Ecological Model}

There are a number of versions of the socio-ecologic model, but for this study we included three major components: individual, social, and geographic factors. Each level (and also cross-level interactions) may impact the behavior of the individual (Stokols 1996). In the model, relationships between people and their environments are reciprocal. Social and physical environments influence the behavior of the individual, while the behavior of the individual, group, or organization may also affect environments (Stokols et al 2003). Full assessment of socio-ecologic relationships requires longitudinal data, which was unavailable for this research. However, the model is also useful for specifying the different factors and their relationships that should be used to assess behavior.

In the social ecology model, behavior is influenced by personal traits, social environment, and physical environment. An individual is at the center of the model, demonstrating that individual traits interact with the social and physical environment of a community. The individual component includes personal factors, for instance, gender, age, ethnicity, and personal preferences and attitudes that may influence a particular behavior. The social environment consists of relationships or attributes of individuals and those with whom they interact, as well as influences from culture and society. The physical environment consists of a community's resources and services available to members of that community. These resources help to modify, change, or influence individual behavior by limiting or encouraging opportunities to engage in the behavior.

\section{Measurement of Variables}

The purpose of this study was to determine factors associated with ever use of contraceptives. The social-ecological variables being used in this study consisted of the following:

Individual factors included the age of respondents measured in six categories (age 15-24, 25-29, 30-34, 35-39, 40-45, and 46-49) and education based on the number of completed years (none, 1-5, 6-9, and 10+).

The social environment was determined by the husband's education (measured in the same way as respondents), number of children (none, 1-2, 3-4, 5-6, 7+), household 
income (less than 10,000, 10,001-15,000,15,001-20,000, above 20,000 rupees), and Living Index, which was a count of the presence of eight household items: radio/radio cassette, television, landline telephone, cellular phone, washing machine, sewing machine, refrigerator/freezer, $\mathrm{CD} / \mathrm{VCD} / \mathrm{DVD}$ player, air conditioner (room cooler), clock, motorcycle, bicycle, and car/jeep/van. These household items have been used in various national and international household surveys to compute a composite living index. The living index was a sum, and the median score in the sample was 6 . Respondents with $<=$ 6 items were considered low in socioeconomic status.

The physical environment was composed of two categories: distance from community services(postal service, banks, firefighting unit, emergency hospital, recreational facilities) and the quality of environmental services (waste water disposal, solid waste disposal, water supply, electricity, cooking fuel, and access to roads). Distance from community services ranged from within 1 kilometer to more than 5 kilometers, and a composite score (none, 1-2, 3-4, and 5) was created to represent the number of community services within $5 \mathrm{~km}$. Respondents also reported on the quality of these community services. We created a subjective quality index based on a summed score (range of 2-11). This index was then categorized as poor (a score of less than 6), fair (a score between 6 and 7), good (a score equal to 8), and excellent (a score of 9 or greater).

\section{Material and Methods}

Data of the present study were drawn from a nationwide study, "Living Conditions in Urban Slums of Selected Cities of Pakistan" jointly conducted by University of Gujrat, Gujrat; UNFPA, Islamabad; UN Habitat, Islamabad. This study was part of UN Habitat project of "Sustainable Urbanization." UN Habitat selected six cities, namely Mansehra, Muzaffarabad, Gilgit, Mingora, Sialkot, and Sukkur. UN Habitat also selected urban slum localities in the cities. The localities were seventeen in all, two from Gilgit and three from each other city. The target population consisted of all house holds that had at least one married woman of age 15-49 years. It was assumed that every household had at least one woman of childbearing age. At least 400 low-income households defined the sampling unit selected for each city. For drawing the sample, all households of the small settlements meeting the inclusion criteria were selected. In settlement shaving more than 400 households and sufficiently large sample size, systematic sampling was used to draw the sample.

Married women age 15-49 were interviewed from sampled households. Households having no married women within the age range were disqualified. In households with more than one married woman, the one, having longest marital status was selected. Response rate of approached respondents was $99 \%$ and a total sample of 2420 married women was recruited across the six cities. 
We developed logistic and multilevel models to assess the strength of association between socio-ecologic indicators and contraceptive use. Analyses were conducted in SPSS and STATA.

\section{Results}

\section{Table 1}

Features of Married Women in Urban Slums, Selected Cities, Pakistan

\begin{tabular}{|l|c|c|c|c|c|c|c|}
\hline \multicolumn{2}{|l|}{ City N } & Mge of the & $\begin{array}{c}\text { Completed } \\
\text { respondent } \\
\text { years of } \\
\text { education }\end{array}$ & $\begin{array}{c}\text { Husband } \\
\text { years of } \\
\text { education }\end{array}$ & $\begin{array}{c}\text { Total } \\
\text { children }\end{array}$ & $\begin{array}{c}\text { Living } \\
\text { index }\end{array}$ & $\begin{array}{c}\text { Environment } \\
\text { Quality } \\
\text { Index }\end{array}$ \\
Mean (SD) & Mean (SD) & Mean (SD) & Mean(SD) & $\begin{array}{c}\text { Mean } \\
\text { (SD) }\end{array}$ & Mean (SD) \\
\hline Mansehra & 410 & $32.9(8.5)$ & $2.4(4.7)$ & $3.0(5.2)$ & $4.2(2.4)$ & $4.6(1.8)$ & $8.0(1.7)$ \\
\hline Muzaffarabad & 408 & $32.6(8.5)$ & $5.2(5.0)$ & $7.6(4.8)$ & $3.7(2.1)$ & $4.7(2.4)$ & $6.9(2.1)$ \\
\hline Gilgit & 401 & $34.5(8.1)$ & $5.7(5.8)$ & $8.6(5.6)$ & $4.4(2.2)$ & $5.1(2.5)$ & $6.8(1.5)$ \\
\hline Mingora & 401 & $31.9(8.5)$ & $1.0(2.7)$ & $2.7(4.3)$ & $4.9(2.8)$ & $2.7(1.2)$ & $6.7(2.0)$ \\
\hline Sialkot & 385 & $33.8(8.0)$ & $5.6(4.6)$ & $5.9(4.9)$ & $3.8(2.0)$ & $6.0(2.2)$ & $7.2(2.4)$ \\
\hline Sukkur & 415 & $34.3(8.3)$ & $3.2(4.8)$ & $6.0(6.1)$ & $4.9(2.5)$ & $4.8(2.3)$ & $7.5(2.1)$ \\
\hline Total & 2420 & $33.4(8.4)$ & $3.8(5.0)$ & $5.6(5.6)$ & $4.3(2.4)$ & $4.6(2.3)$ & $7.2(2.0)$ \\
\hline
\end{tabular}

Descriptive statistics for the six cities showed that Mingora had the lowest mean age (31.9). Mingora also had the lowest level of education, with a mean of 1 year. Gilgit had the highest mean education,witha mean of 5.7 completed years. Gilgit also showed the highest mean education of respondents' husbands, 8.6 years. Sialkot showed the highest living index score (6.0), whereas Mansehra had the highest environment quality (8.0).

Table 2

Respondents' ever use of Contraceptive

\begin{tabular}{|l|c|}
\hline City & $\begin{array}{c}\text { Percentage of respondents ever } \\
\text { used contraceptive }\end{array}$ \\
\hline Mansehra & $35.9 \%$ \\
\hline Muzaffarabad & $41.7 \%$ \\
\hline Gilgit & $44.1 \%$ \\
\hline Mingora & $2.7 \%$ \\
\hline Sialkot & $33.8 \%$ \\
\hline Sukkur & $19.5 \%$ \\
\hline
\end{tabular}

In regard to use of contraceptives Mingora showed the lowest percentage $(2.7 \%)$ of ever use of contraceptives whereas Gilgit showed the highest percentage (44.1\%). 
An Exploration of Individual and Contextual Factors Affecting the Use of Contraceptives in Urban Slums of Pakistan: A Socio-ecological Analysis

Table 3

Unadjusted Bivariate Odds Ratios for the use of Contraceptives by Individual and Social-level Variables.

\begin{tabular}{|c|c|c|c|c|c|c|}
\hline Use of Contraceptive & $\begin{array}{l}\text { Odds } \\
\text { Ratio } \\
\end{array}$ & $\begin{array}{c}\text { Robust Std. } \\
\text { Err } \\
\end{array}$ & $\mathbf{Z}$ & $\mathbf{P}>\mathbf{Z}$ & \multicolumn{2}{|c|}{$95 \% \quad C I$} \\
\hline \multicolumn{7}{|l|}{ Age } \\
\hline \multicolumn{7}{|l|}{$15-24$} \\
\hline $25-29$ & 2.21246 & 0.2581042 & 6.81 & 0 & 1.760252 & 2.780841 \\
\hline $30-34$ & 2.585015 & 0.3991246 & 6.15 & 0 & 1.910021 & 3.498549 \\
\hline $35-39$ & 2.241443 & 0.5918374 & 3.06 & 0.002 & 1.3359 & 3.760812 \\
\hline $40-45$ & 1.75301 & 0.4068606 & 2.42 & 0.016 & 1.112313 & 2.762753 \\
\hline $46-50$ & 0.9928315 & 0.1554994 & -0.05 & 0.963 & 0.7303963 & 1.349561 \\
\hline \multicolumn{7}{|l|}{ Education of Women } \\
\hline \multicolumn{7}{|l|}{ None } \\
\hline Less than Secondary & 2.048785 & 0.7058722 & 2.08 & 0.037 & 1.042869 & 4.02497 \\
\hline Secondary and above & 1.793582 & 0.6768673 & 1.55 & 0.122 & 0.8560368 & 3.75943 \\
\hline \multicolumn{7}{|l|}{ Education of Husband } \\
\hline \multicolumn{7}{|l|}{ None } \\
\hline Less than Secondary & 1.433017 & 0.4902133 & 1.05 & 0.293 & 0.7329394 & 2.801782 \\
\hline Secondary and above & 1.571427 & 0.6314395 & 1.12 & 0.261 & 0.7149241 & 3.454051 \\
\hline \multicolumn{7}{|l|}{$\begin{array}{l}\text { Total number of } \\
\text { Children }\end{array}$} \\
\hline \multicolumn{7}{|l|}{ None } \\
\hline $1-2$ & 4.207298 & 3.44539 & 1.75 & 0.079 & 0.8451766 & 20.94397 \\
\hline $3-4$ & 5.600538 & 4.700104 & 2.05 & 0.04 & 1.081139 & 29.01204 \\
\hline $5-6$ & 5.616972 & 4.704642 & 2.06 & 0.039 & 1.087818 & 29.00336 \\
\hline $7+$ & 3.107538 & 2.643226 & 1.33 & 0.183 & 0.586674 & 16.46023 \\
\hline \multicolumn{7}{|l|}{$\begin{array}{l}\text { Household Income } \\
\text { (PK RS) }\end{array}$} \\
\hline \multicolumn{7}{|l|}{ Less than 10,000} \\
\hline $10,001-15,000$ & 2.412846 & 0.6600172 & 3.22 & 0.001 & 1.411527 & 4.124486 \\
\hline $15,001-20,000$ & 1.970885 & 0.6773958 & 1.97 & 0.048 & 1.004852 & 3.865631 \\
\hline Above 20,000 & 2.346452 & 1.090351 & 1.84 & 0.066 & 0.9437888 & 5.833762 \\
\hline \multicolumn{7}{|l|}{ Living Index } \\
\hline \multicolumn{7}{|l|}{ Low } \\
\hline High & 1.738028 & 0.588757 & 1.63 & 0.103 & 0.8947715 & 3.375991 \\
\hline \multicolumn{7}{|l|}{$\begin{array}{l}\text { Environment Quality } \\
\text { Index }\end{array}$} \\
\hline \multicolumn{7}{|l|}{ Poor } \\
\hline Fair & 1.097951 & 0.1937676 & 0.53 & 0.596 & 0.7768946 & 1.551687 \\
\hline Good & 1.366008 & 0.2941399 & 1.45 & 0.147 & 0.8957062 & 2.083247 \\
\hline Excellent & 2.323257 & 0.6627251 & 2.96 & 0.003 & 1.32827 & 4.063576 \\
\hline \multicolumn{7}{|l|}{$\begin{array}{l}\text { Access to Community } \\
\text { Services }\end{array}$} \\
\hline \multicolumn{7}{|l|}{ No Service within $5 \mathrm{KM}$} \\
\hline $\begin{array}{l}\text { 1-2 Services within } \\
5 \mathrm{KM}\end{array}$ & 3.22973 & 1.95347 & 1.94 & 0.053 & 0.9870189 & 10.56834 \\
\hline $\begin{array}{l}\text { 3-4 Services within } \\
5 \mathrm{KM}\end{array}$ & 3.490627 & 2.539919 & 1.72 & 0.086 & 0.8385622 & 14.5302 \\
\hline 5 services within $5 \mathrm{~km}$ & 3.487752 & 2.630091 & 1.66 & 0.098 & 0.7955364 & 15.29083 \\
\hline
\end{tabular}

Note: Environment quality index was constructed based on subjective quality index (range of 2 - 11) based on perceived quality of services (waste water disposal, solid waste disposal, water supply, electricity, 
cooking fuel, and access to roads) that were most important for community health. This index was then categorized into four categories: poor (a score of less than 6), fair (a score between 6 and 7), good (a score equal to 8), and excellent (a score of 9 or greater). ${ }^{a} \mathrm{PK}$ Rs represents Pakistani Rupees. ${ }^{b} \mathrm{KM}$ represents Kilometer

Results of Bivariate logistic analysis showed that age was significantly associated with use of contraceptives. Relative to women aged 15-24, there was an increase in use of contraceptives for married women aged 25-29 to 30-34; the odds ratio increased from 2.212 to 2.585.Among women aged 35-39, the odds ratio for contraceptive use was 2.241. At the age of 40-45 there was decrease in use of contraceptives with odds ratio 1.753. At 46-50,age was no longer associated with use of contraceptives. The education of respondents was also significantly associated with use of contraceptives. Respondents with less than secondary education compared to no education at all were 2.0487 times more likely to use contraceptives. Number of children was also associated with use of contraceptives. Women with 3-4 and 5-6 children are more likely to use contraceptives with odds 5.60 and 5.61 respectively. Income has always been associated with use of contraceptives and our analysis supports this finding, as respondents whose income was between Rs 10,001 to 15,000 were 2.412 times more likely to use contraceptives compared to respondents who had income less than Rs10,000. With further increase, however, contraceptive use declined.

The living index of respondents was not significantly associated with use of contraceptive methods, while the environmental quality index showed that respondents who reported excellent environmental quality index were 2.323 times more likely to use contraceptives.

Women were three times more likely to use contraception if they had at least one service within five $\mathrm{km}$ compared to those with no service within five $\mathrm{km}$.

\section{Multivariate Analysis}

The clustered nature of the data necessitated the application of a statistical modeling approach that can takes into account the fact that the observations with each of the six districts are not independent. We use multivariate logistic regressions and specify districts as clusters and then calculate robust standard errors. The dependent variable is "ever use of contraceptive" is a binary variable coded as " 0 " if the respondent had never used contraceptive and " 1 " if they had ever used contraceptives. 
Slums of Pakistan: A Socio-ecological Analysis

Table 4

Adjusted Odds Ratios for Contraceptive Use based on Multivariate Logistic Regression Model

\begin{tabular}{|c|c|c|c|c|c|c|}
\hline \multirow{2}{*}{\begin{tabular}{|c|} 
Use of Contraceptives \\
Education of Women \\
\end{tabular}} & \multirow{2}{*}{$\begin{array}{l}\text { Odds } \\
\text { Ratio } \\
\end{array}$} & \multirow{2}{*}{$\begin{array}{c}\text { Robust Std. } \\
\text { Err. }\end{array}$} & \multirow[t]{2}{*}{$\mathbf{z}$} & \multirow[t]{2}{*}{$\mathbf{P}>\mathbf{Z}$} & \multicolumn{2}{|c|}{$95 \% \mathrm{CI}$} \\
\hline & & & & & & \\
\hline \multicolumn{7}{|l|}{ None } \\
\hline Less than Secondary & 1.700401 & 0.38203 & 2.36 & 0.018 & 1.094741 & 2.641139 \\
\hline Secondary and above & 1.314025 & 0.2194946 & 1.63 & 0.102 & 0.9471509 & 1.823007 \\
\hline \multicolumn{7}{|l|}{ Education of Husband } \\
\hline \multicolumn{7}{|l|}{ None } \\
\hline Less than secondary & 1.229414 & 0.1825924 & 1.39 & 0.164 & 0.9189206 & 1.644821 \\
\hline Secondary and above & 1.204346 & 0.214176 & 1.05 & 0.296 & 0.8499177 & 1.706575 \\
\hline \multicolumn{7}{|l|}{$\begin{array}{l}\text { Total number of } \\
\text { children }\end{array}$} \\
\hline \multicolumn{7}{|l|}{ None } \\
\hline $1-2$ & 4.938244 & 4.317854 & 1.83 & 0.068 & 0.8898306 & 27.40551 \\
\hline $3-4$ & 6.960483 & 6321838 & 2.14 & 0.033 & 1.173649 & 41.28009 \\
\hline $5-6$ & 7.955282 & 7.118637 & 2.32 & 0.02 & 1.1377126 & 45.95551 \\
\hline $7+$ & 4.69577 & 4.375209 & 1.66 & 0.097 & 0.7561597 & 29.16085 \\
\hline \multicolumn{7}{|l|}{ Total Income PK RS } \\
\hline \multicolumn{7}{|l|}{ Less than 10,000} \\
\hline $10,000-15,000$ & 1.943332 & 0.3397568 & 3.8 & 0 & 1.379525 & 2.737564 \\
\hline $15,001-20,000$ & 1.529016 & 0.2302427 & 2.82 & 0.005 & 1.138246 & 2.053941 \\
\hline Above 20,000 & 1.433911 & 0.3275678 & 1.58 & 0.115 & 0.9163697 & 2.243746 \\
\hline \multicolumn{7}{|l|}{ Living Index } \\
\hline \multicolumn{7}{|l|}{ Low } \\
\hline High & 1.181478 & 0.1764915 & 1.12 & 0.264 & 0.8816003 & 1.583361 \\
\hline \multicolumn{7}{|l|}{$\begin{array}{l}\text { Environment quality } \\
\text { index }\end{array}$} \\
\hline \multicolumn{7}{|l|}{ Poor } \\
\hline Fair & 0.8495562 & 0.1650489 & -0.84 & 0.401 & 0.5805285 & 1.243256 \\
\hline Good & 0.9897508 & 0.3672859 & -0.03 & 0.978 & 0.478249 & 2.048319 \\
\hline Excellent & 1.66835 & 0.3365578 & 2.54 & 0.011 & 1.123501 & 2.477427 \\
\hline \multicolumn{7}{|l|}{$\begin{array}{l}\text { Access to Community } \\
\text { Services in } \mathbf{k m}\end{array}$} \\
\hline \multicolumn{7}{|l|}{ No Service within $5 \mathrm{KM}$} \\
\hline $\begin{array}{l}\text { 1-2 Services within } 5 \\
\text { KM }\end{array}$ & 2.972459 & 1.476437 & 2.19 & 0.028 & 1.122844 & 7.868869 \\
\hline $\begin{array}{l}\text { 3-4 Services within } 5 \\
\text { KM }\end{array}$ & 3.211684 & 1.901021 & 1.97 & 0.049 & 1.006699 & 10.24627 \\
\hline 5 Services within $5 \mathrm{KM}$ & 3.421879 & 2.166698 & 1.94 & 0.052 & 0.98922 & 11.83686 \\
\hline
\end{tabular}

Table 3 presents unadjusted bivariate odds and table 4 present odds ratios that are adjusted for covariates. The odds ratios in both tables are based on robust standard errors calculated using STATA 12 software package (StataCorp. 2011. Statistical Software: Release 12. College Station, TX: StataCorp LP). The odds of using contraception are higher in age groups 25-29 and 30-34 compared to 15-19 age group. There are higher odds of ever using contraception among the women with less than secondary education compared to none. Husband's education is not significant related to contraceptive use. 
Household income has a weak relationship with contraceptive use with women the 10,000-15,000 showing significant higher odds compared to those making less than 10,000 rupees. The total number of children in a family is strongly and significantly related to contraceptive use. The odds ratios of using contraception for those women with one or more children are at least three fold greater than those with no children.

The chances of using contraception for those women who reported excellent quality index are 1.668 times more compared to women with poor environment quality index. In regard to access to community services the odds ratio of using contraception for those women who reported 1-2 and 3-4 services within $5 \mathrm{~km}$ are at least two and three fold greater respectively than those who have no service within $5 \mathrm{~km}$.

\section{Discussion}

In the current study married women between 15 to 50 years were interviewed from sampled households. Mingora had lowest mean age of 31.9 compared to other five cities. Regarding completed years of education of respondents, Mingora scored lowest with mean equals to one year. Highest mean education was found in Gilgit where respondents had a mean of 5.7 completed years of education. Gilgit also showed the highest mean education of respondents' husband's (8.6). On the other hand, Sialkot showed the highest mean (6.0) for living index and Mansehra carried the highest mean (8.0) for environment quality index.

In logistic regression models, individual and social factors were significant correlates of contraception practices, but community-level geographic factors also explained variance in contraception use. Ignoring area-level factors would be a mistake because even with adjustment for individual level factors, location remained a significant correlate of contraception use.

Results from this research are in accord with prior literature on correlates of ever use of contraception in developing counties. Older women were less likely to report use of contraception. This finding may represent a cohort effect, in which these women had less access to contraception than more recent cohorts. This finding was also validated by multilevel analysis, which confirmed the greater odds of using contraception among women aged 25-29 and 30-34 compared to older women.

Education of women has long been associated with use of contraceptives (Kora 2002). Our study supports this finding as results suggest that women with relatively low levels of education, such as less than secondary schooling, were more likely to use contraceptives compared to women with no education. Researchers argue that education helps to increase the status and autonomy of women, and that these gains in turn lead to greater use of contraceptives (Saleem \& Bobak 2005). This reasoning may apply to the poor women surveyed here. Education seems to play an important role even in urban slums. It may make 
these women aware of the advantages of limiting childbearing and help them appreciate the advantages of having fewer but better educated children (Okezie, Ogbel\& Okezie 2010).

Socioeconomic status has also been associated with use of contraception. Results of both logistic and multilevel analysis support household income as a correlate of contraceptive use even in the generally low-income communities in this sample. In these urban slums, where all sampled respondents are of low socioeconomic status, household income still affects use of contraceptives.

Procreation is one of the most important objectives of marriage (Kridli \& Libbus 2001) in most Muslim societies, and producing children is an important function of marriage. Notably, contraceptive use among women with children was three fold greater than among women without children. This suggests that contraception was mostly used to limit family size.

Overall, this analysis suggests the value of the socio-ecologic model in addressing correlates of contraceptive use. An important demonstration of the influence of different socio-ecologic levels is the key role of place, that is, area-level factors associated with the six different urban slums. Location remained a significant correlate even with adjustment for individual and social factors, and even after we included individual ratings of access to community services and environmental quality. If community or area-level factors explain variance in contraception use after adjustment for individual and social factors, as this research suggests, then increases in contraception use will likely require interventions at the level of the community, that is, policy and environmental change to support family planning.

Findings from this research should be interpreted within the limitations of our crosssectional design. Response rates and survey quality were high, so bias is unlikely from this source. However, all data were self-reported and the key measure of contraceptive use was based on retrospective report. Still, the robust and consistent associations across the six sites suggest a key role for different levels of social ecology and the value of focusing on both individual and areal factors in contraception use.

\section{Acknowledgements}

This study was conducted with financial assistance of UNFPA, Islamabad and technical assistance of UN, Habitat, Islamabad.

\section{References}

Agha, S. (2010). Intentions To Use Contraceptives In Pakistan: Implications For Behavior Change Campaigns, BMC Public Health, p, 450. 
Agha, S. (2001). Is Low Income A Constraint To Contraceptive Use Among The Pakistani Poor?, Journal of Biosocial Science, pp, 165-175.

Ali, S. \& White, F. (2005). Family Planning Practices Among Currently Married Women In Khairpur District Sindh Pakistan, Journal of College of Physicians and Surgeons Pakistan 15 (7), pp, 422-425.

Axinn, W.G. \& Yadiko, S. (2001). Social Change, The Social Organization Of Families, And Fertility Limitation, American Journal of Sociology106, pp, 1219-1261.

Axinn, W.G. \& Barber, J.S. (2001). Mass Education And Fertility Transition, American Sociological Review, 6(4), pp, 481-505.

Bhatti, M.U.H. \& Hakim, A. (1996). Male Attitudes And Motivation For Family Planning In Pakistan, The Pakistan Development Review42, pp, 197-217.

Biddlecom, A.E., Axinn, W. \& Barber, J.S. (2005). Environmental Effects On Family Size Preferences And Subsequent Reproductive Behavior In Nepal', Population and Environment26, pp. 583-621.

Casterline, J. Sathar, Z. A. \& Haque, M. (2001). Obstacles To Contraceptive Use In Pakistan: A Study In Punjab, Studies In Family Planning 32, pp, 95-110

Douthwaite, M. \& Ward, P. (2005). Increasing Contraceptive Use In Rural Pakistan: An Evaluation Of The Lady Health Worker Programme, Health Policy and Planning20, pp, 117-123.

Dunlap, R.E., Gallup, G.H.Jr. \& Gallup, A.M. (1993). Health Of The Planet, George Gallup International Institute, Princeton.

Durrant, V. \& Sathar, Z. (2000). Greater Investments In Children Through Women's Empowerment: The Key To Demographic Change In Pakistan? Paper Presented At The Annual Meeting Of The Population Association Of America, Los Angeles, USA.

Fikree, F.F., Khan, A., Kadir, M.M., Sajan, F. \& Rahbar, M.H. (2001). What Influences Contraceptive Use Among Young Women In Urban Squatter Settlements Of Karachi, Pakistan?, International Family Planning Perspectives27, pp, 130-6.

Ghimire, D.J. \& Mohai. P. (2005). Environmentalism And Contraceptive Use: How People In Less Developed Settings Approach Environmental Issues, Population and Environment 27, pp, 29-61. 

Slums of Pakistan: A Socio-ecological Analysis

Hakim, A. (2001). Population Policy Shifts And Their Implications For Population Stabilization In Pakistan, The Pakistan Development Review 40, pp, 551-73.

Hakim, A. \& Miller, P.C. (2001). Family Planning In Pakistan: A Turning Point In Sathar, Z.A. And Philips, J.F eds Fertility Transition in South Asia, Oxford University Press.

Hamid, S., Stephenson, R. \& Rubenson, B. (2011). Marriage Decision Making, Spousal Communication, And Reproductive Health Among Married Youth In Pakistan, Global Health Action4, pp, 5079.

Haq, A. S., Vanwing, T. \& Hens, L. (2010). Perception, Environmental Degradation And Family Size Preference: Acontext Of Developing Countries, Journal of Sustainable Development 3, pp, 102-108.

Hardee, K. \& Leahy, E. (2008). Population, Fertility And Family Planning In Pakistan: A Program In Stagnation, Population Action International 3(3), pp, 1-12.

Korra, A. (2002). Attitudes Toward Family Planning, And Reasons For Non-Use Among Women With Unmet Need For Family Planning In Ethiopia, Maryland, Marco Books.

Kridli, S. \& Libbus, K. (2001). Contraception in Jordan: A cultural and religious perspective, International Nursing Review 48, pp, 144-51.

Maqsood, F. (2010). Social Exclusion And Use Of Contraceptive Methods Among Women In Pakistan, The Pakistan Journal of Social Issues 1, pp, 31-43

Mason, K.O. (2000). Husbands versus Wives Fertility Goals And Use Of Contraception: The Influence Of Gender Context In Five Asian Countries, Demography 37, pp, 299-311.

McBride, J. \& Ahmed, R. (2001). Social Franchising As A Strategy For Expanding Access To Reproductive Health Services: A Case Study Of The Green Star Service Delivery Network In Pakistan, Commercial Market Strategies, Washington, DC.

Okezie, C.A., Ogbel, A.O. \& OkezieC, R. (2010). Socio-Economic Determinants Of Contraceptive Use Among Rural Women In Ikwuano Local Government Area Of Abia State, Nigeria International NGO Journal 5, pp, 74-77. 
Saleem, S. \& Bobak, M. (2005). Women's Autonomy, Education, And Contraceptive Use In Pakistan: A National Study, Reproductive Health2, pp, 1-8.

Schultz, T. (2002). Why Governments Should Invest More To Educate Girls, World30, pp, 207-225.

Stephenson, R. \& Hennink, M. (2004). Barriers To Family Planning Service Use Among The Urban Poor In Pakistan, Opportunities and Choices Working Paper2, pp, 1-34.

Stokols, D., Grzywacz. J.G., McMahan, S. \& Phillips, K. (2003). Increasing The Health Promotive Capacity Of Human Environments In American Journal of Health Promotion 18, pp, 4-13.

Stokols, D. (1995). Establishing And Maintaining Health Environments: Toward A Social Ecology Of Health Promotion In American Psychologist 47, pp, 6-22.

Sultan, M., Cleland, J., \& Ali, M. (2002). Assessment Of A New Approach To Family Planning Services In Rural Pakistan In American Journal of Public Health, pp, 1168-1172.

Toll, K. \& Agha, S. (1999). Country Watch: Pakistan, Sexual Health Exchange 1, pp, 7-8.

United Nations (2009). World Prospects 2008. New York: UN Department of Economic and Social Affairs, Population Division.

Westoff, C. F. \& Bankole, A. (2000). Trends In The Demand For Family Limitation In Developing Countries, International Family Planning Perspectives 26, pp, 56-62.

Winkvist, A. \& Akhtar, A. (2000). God Should Give Daughters To Rich Families Only: Attitudes Towards Childbearing Among Low-Income Women In Punjab, Pakistan, Social Science and Medicine 51, pp, 73-81.

Fauzia Maqsood is Assistant Professor in the Department of Sociology, University of Gujrat, Pakistan.

Steven M. Albert is Professor and Chair in the Department of Behavioral and Community Health Sciences Graduate School of Public Health, University of Pittsburgh, USA. 